\title{
Integrated assessment and mechanism of ecologization of the economy for achievement of sustainable regional development
}

\author{
Yulia Vertakova \\ South-West State University, \\ Institute of Economics and Management \\ Head of Department of Regional Economics and \\ Management \\ Kursk, Russia \\ vertakova7@yandex.ru
}

\author{
Elena Kondratova \\ South-West State University, \\ Institute of Economics and Management \\ Department of Regional Economics and Management \\ Kursk, Russia \\ kondratova.elena.95@mail.ru
}

\author{
Alexander Babkin \\ Peter the Great St.Petersburg Polytechnic University \\ The higher engineering and economic school \\ St. Petersburg, Russia. \\ babkin@spbstu.ru
}

\begin{abstract}
Currently, one of the areas of economic regulation in order to achieve sustainable development is the development of "green economy". The environmentally sound economy paradigm seeks to provide a comprehensive framework for stimulating investment in the environment, reducing poverty and promoting sustainable economic growth. Thus, the environment should no longer be seen as an obstacle to growth but rather as its engine.
\end{abstract}

Keywords - sustainable development, greening mechanism," green economy", region

\section{INTRODUCTION}

Regional environmental policy is mainly aimed at solving problems in the field of environmental protection and improving environmental performance. In our opinion, the environmental policy stimulating transition of subjects of the Russian Federation to "green economy" will promote the achievement of nature protection result and economic growth at the regional level simultaneously. The environmental and economic policies of the Russian regions should not be isolated from each other. The regional authorities of different subjects of the Russian Federation should be in close and productive interaction.

Greening the economy is an integral part of sustainable regional development. The main direction of ecologization of the economic development in the subjects of the Russian
Federation is to reduce the natural intensity of economic processes, which is possible due to the effective use of natural resources, reducing pollution and industrial waste, the introduction of innovative resource-saving technologies, the development of high-tech activities.

There are many approaches to determining the level of ecologization of the economy: the use of the system of indicators (nature capacity, environmental activity, resource allocation, etc.), the use of an indicative method, etc.

\section{MATERIALS AND METHODS (MODEL)}

In this research the method of assessment of ecological and economic territorial development based on the calculation of the integral index is used in order to determine the level of ecologization of the regional economy. The advantages of this technique are the possibility of comparative analysis of the Russian regions in terms of environmental and economic development, as well as the absence of expensive software and expert procedures during its implementation.

The integrated assessment of the level of ecologization of the region's economy consists of two stages. Due to the fact that ecological and economic regional development depends on different factors, at the initial stage, 14 basic indicators characterizing the ecological and economic situation in the subject of the Russian Federation are used to determine the integral indicator of the ecologization of the region's economy. 
In determining the indicators of pollution intensity in the subjects of the country the interregional differentiation in the vastness of the territory, the level of GRP, population are taken into account.

Thus, the following indicators were selected to calculate the index:

1. emissions of pollutants into the ambient air per unit of GRP;

2. emissions of pollutants into the atmospheric air per capita;

3. generation of production and consumption waste per area unit;

4. emissions of polluting substances into atmospheric air;

5. discharge of polluted wastewater into surface water bodies per GRP unit;

6. generation of production and consumption waste per GRP unit;

7. discharge of contaminated wastewater into surface water bodies per unit area;

8. discharge of polluted wastewater into surface water bodies per capita;

9. generation of production and consumption waste per capita;

10. gross regional product per capita;

11. innovation activity of organizations;

12. investments in fixed capital per capita;

13. share of forests and other wooded land;

14. degree of depreciation of fixed assets.

The indicators are multidirectional - they have either a positive or a negative impact on the ecological and economic development of the territory.

The next stage of the study is to determine from the total number of all regions under consideration one reference region that has the best indicator value - maximum or minimum (hereinafter this value is taken as a unit).

Then the comparative analysis in a share ratio of the leading region with other subjects of the Russian Federation on the following formulas is carried out:

Article is prepared within researches on the project of the Russian fund of basic researches, the project No. 18-01001119.

$$
\ln _{i}^{n}=\frac{Y_{i}^{n}}{Y_{\max }^{n}} \text { или } \ln _{i}^{n}=\frac{Y_{\min }^{n}}{Y_{i}^{n}} \text {, where }
$$

$Y_{i}^{n}$ - value of the $\mathrm{n}^{\text {th }}$ base indicator for the $\mathrm{i}^{\text {th }}$ region;

$Y_{\max }^{n}, Y_{\min }^{n}$ - the best maximum or minimum value of the $\mathrm{n}^{\text {th }}$ base indicator,

$\ln n_{i}^{n}$ - assessment of the level of development of the $i^{\text {th }}$ region in relation to the leading region of the $\mathrm{n}^{\text {th }}$ base indicator.

Further calculation of the arithmetic value of the basic indicators' indices for each region under study, the results of which are the ranked territories according to the descending order degree.

At the final stage, the country subjects are interpreted according to the level of ecologization of the regional economy, in which regions with different levels of ecological and economic development (extremely low, low, medium, above average, high) are distinguished.

The methodology for determining the level of ecologization of the economy was tested on the example of the regions of the Central Federal District (CFD), located in the West of the European part of the Russian Federation. It consists of 18 constituent entities of the Russian Federation: Belgorod oblast, Bryansk oblast, Vladimir oblast, Voronezh oblast, Ivanovo oblast, Kaluga oblast, Kostroma oblast, Kursk oblast, Lipetsk oblast, Moscow oblast, the city of Moscow, Orel oblast, Ryazan oblast, Smolensk oblast, Tambov oblast, Tver oblast, Tula oblast, Yaroslavl oblast.

\section{RESULTS AND DISCUSSION}

The results of the integrated assessment of ecologization of the regions of the Central Federal District are presented in table 1 .

During the considered time period in the rating of ecologization of the regional economy movements are revealed. The dynamics of the results of the integrated index of ecologization of the regional economy indicates that a slight improvement in environmental and economic development during the study period in the Central Federal District occurred in the Vladimir, Kostroma, Lipetsk, and Yaroslavl regions. This indicates the effectiveness of measures to stimulate sustainable environmental and economic development of these subjects of the Russian Federation, i.e. successful implementation of the concept of sustainable development at the regional level [5].

All the other entities can be noted as decreasing in the integrated index, which, in the end, influenced the deterioration of the level of ecologization of the economy in Kaluga, Orel, and Tver regions and in the city of Moscow. 
Table 1. Results of integrated assessment of ecologization of regions of the Central Federal district

\begin{tabular}{|c|c|c|c|c|c|}
\hline \multirow{2}{*}{$\begin{array}{l}\text { Constituent } \\
\text { entity of the } \\
\text { Russian } \\
\text { Federation }\end{array}$} & \multicolumn{2}{|c|}{$\begin{array}{l}\text { The value of the } \\
\text { integrated index } \\
\text { (ranking place) }\end{array}$} & \multicolumn{3}{|c|}{$\begin{array}{c}\text { Characteristics of the } \\
\text { regional level of } \\
\text { sustainability of ecological } \\
\text { and economic development }\end{array}$} \\
\hline & 2005 & 2015 & 2005 & 2015 & $\begin{array}{l}\text { Index } \\
\text { change }\end{array}$ \\
\hline $\begin{array}{c}\text { Belgorod } \\
\text { oblast }\end{array}$ & $0,367(7)$ & $\begin{array}{c}0,307 \\
(\mathbf{9})\end{array}$ & Low & Low & $-0,06$ \\
\hline $\begin{array}{c}\text { Bryansk } \\
\text { oblast }\end{array}$ & $\begin{array}{c}0,371 \\
\mathbf{( 1 0 )} \\
\end{array}$ & $\begin{array}{c}0,262 \\
\mathbf{( 1 6 )} \\
\end{array}$ & Low & Low & $-0,109$ \\
\hline $\begin{array}{l}\text { Vladimir } \\
\text { oblast }\end{array}$ & 0,32 (13) & $\begin{array}{c}0,381 \\
\mathbf{( 3 )}\end{array}$ & Low & Low & 0,061 \\
\hline $\begin{array}{c}\text { Voronezh } \\
\text { oblast }\end{array}$ & $0,393(\mathbf{6})$ & $\begin{array}{c}0,305 \\
(\mathbf{1 0}) \\
\end{array}$ & Low & Low & $-0,088$ \\
\hline $\begin{array}{c}\text { Ivanovo } \\
\text { oblast }\end{array}$ & $\begin{array}{c}0,361 \\
\mathbf{( 1 1 )}\end{array}$ & $\begin{array}{c}0,349 \\
\mathbf{( 6 )}\end{array}$ & Low & Low & $-0,012$ \\
\hline Kaluga_oblast & $0,486(\mathbf{1})$ & $\begin{array}{c}0,324 \\
(\mathbf{8}) \\
\end{array}$ & $\begin{array}{c}\text { Mediu } \\
\mathrm{m}\end{array}$ & Low & $-0,162$ \\
\hline $\begin{array}{c}\text { Kostroma } \\
\text { oblast }\end{array}$ & $\begin{array}{c}0,319 \\
\mathbf{( 1 4 )} \\
\end{array}$ & $\begin{array}{c}0,378 \\
\mathbf{( 4 )} \\
\end{array}$ & Low & Low & 0,059 \\
\hline Kursk oblast & $0,376(\mathbf{8})$ & $\begin{array}{c}0,247 \\
\mathbf{( 1 7 )} \\
\end{array}$ & Low & Low & $-0,129$ \\
\hline Lipetsk oblast & $\begin{array}{c}0,227 \\
\mathbf{( 1 8 )} \\
\end{array}$ & $\begin{array}{c}0,359 \\
\mathbf{( 5 )} \\
\end{array}$ & Low & Low & 0,132 \\
\hline Moscow oblast & $0,476(2)$ & $\begin{array}{c}0,421 \\
\text { (2) }\end{array}$ & $\begin{array}{c}\text { Mediu } \\
\mathrm{m}\end{array}$ & $\begin{array}{c}\text { Mediu } \\
\mathrm{m}\end{array}$ & $-0,055$ \\
\hline Orel_oblast & $0,439(\mathbf{5})$ & $\begin{array}{c}0,267 \\
(\mathbf{1 5})\end{array}$ & $\begin{array}{c}\text { Mediu } \\
\text { m }\end{array}$ & Low & $-0,172$ \\
\hline Ryazan oblast & $\begin{array}{c}0,345 \\
(\mathbf{1 2}) \\
\end{array}$ & $\begin{array}{c}0,298 \\
(\mathbf{1 1})\end{array}$ & Low & Low & $-0,047$ \\
\hline $\begin{array}{c}\text { Smolensk } \\
\text { oblast }\end{array}$ & $0,382(7)$ & $\begin{array}{c}0,295 \\
(\mathbf{1 2})\end{array}$ & Low & Low & $-0,087$ \\
\hline Tambov oblast & $0,373(\mathbf{9})$ & $\begin{array}{c}0,341 \\
(7) \\
\end{array}$ & Low & Low & $-0,032$ \\
\hline Tver oblast & 0,465 (3) & $\begin{array}{c}0,287 \\
(\mathbf{1 3})\end{array}$ & $\begin{array}{c}\text { Mediu } \\
\mathrm{m}\end{array}$ & Low & $-0,178$ \\
\hline Tula oblast & $\begin{array}{c}0,308 \\
\mathbf{( 1 5 )} \\
\end{array}$ & $\begin{array}{c}0,277 \\
\text { (14) }\end{array}$ & Low & Low & $-0,031$ \\
\hline$\frac{\text { Yaroslavl }}{\text { oblast }}$ & $\begin{array}{c}0,272 \\
(\mathbf{1 6}) \\
\end{array}$ & $\begin{array}{c}0,595 \\
\text { (1) }\end{array}$ & Low & $\begin{array}{c}\text { Mediu } \\
\mathrm{m}\end{array}$ & 0,323 \\
\hline $\begin{array}{l}\text { the city of } \\
\text { Moscow }\end{array}$ & $0,444(\mathbf{4})$ & $\begin{array}{c}0,199 \\
\mathbf{( 1 8 )} \\
\end{array}$ & $\begin{array}{c}\text { Mediu } \\
\mathrm{m}\end{array}$ & Low & $-0,245$ \\
\hline Characteristic & $\begin{array}{r}\text { the region } \\
\text { and econ } \\
\mathrm{Led} \\
\mathrm{Hi}\end{array}$ & $\begin{array}{l}\text { l level } \\
\text { mic dev } \\
w-0,1- \\
\text { um }-0,\end{array}$ & $\begin{array}{l}\text { sustaina } \\
\text { lopment: } \\
4 \\
-0,7 \\
0 . \\
\end{array}$ & ity of & logical \\
\hline
\end{tabular}

In such entities of the Central Federal District as the Belgorod, Bryansk, Voronezh, Ivanovo, Kursk, Moscow, Ryazan, Smolensk, Tambov, and Tula regions there is a process of deecologization of the economic activity, which requires immediate development and implementation of a set of stimulating measures for the transition of these subjects to an environmentally oriented or "green economy".
Interfax-ERA has developed an effective methodology for assessing environmentally sustainable development, which relies on directly measurable and constantly measured data of material objects (including living organisms), their consumption of resources and energy, i.e. on the characteristics of real events and processes in their mutual relation and dynamics. This is a unique methodology for the analysis of environmental and energy efficiency, which allows monitoring the effectiveness of sustainable development programs in the Russian regions (in Ecology and energetics at the ten topics [Text]. - M.: Moscow, ANO "Independent ecological rating Agency", 2016. - 65 p.).

The environmental rating is the most objective tool for managerial decision-making and system solutions to regional problems. The following materials are grouped by Federal District for the convenience of the analysis. Each of them contains four tables, each of which summarizes the ranking of regions according to the following criteria (Fig.1).

\begin{tabular}{|c|c|c|}
\hline $\begin{array}{c}\text { state and } \\
\text { development of } \\
\text { technical potential }\end{array}$ & $\begin{array}{c}\text { state and } \\
\text { development of } \\
\text { human potential }\end{array}$ \\
\hline $\begin{array}{c}\text { state and changes } \\
\text { of nature potential }\end{array}$ & $\begin{array}{c}\text { sustainable } \\
\text { development } \\
\text { potential }\end{array}$ \\
\hline
\end{tabular}

Fig.1 Criteria used to find the ranking results in the environmental ranking

The ranking of the regions of the Central Federal District in the list by the level of development of technical potential is shown in table 2. Here the attention is drawn not so much to the expected championship of the Moscow region as the ranking place of Moscow in the tail on one of the components - ecological energy efficiency. It is this indicator that says that the economy of the capital is developing because of the environment, and its "engine" is more and more "smoking" [6,7]. Only the first place of Moscow in terms of the dynamics of efficiency is somewhat pleasing, which reflects the attention paid to this problem in recent years. The leading position of the Vladimir region in the ranking attracts attention as it shows that the technical potential of the region, being much smaller than of the capital, uses the available energy capacity and scarce development resources most effectively and environmentally safely. 
Table 2. Ranking of the Central Federal district according to the criteria of the state and development of technical potential in 2016

\begin{tabular}{|c|c|c|c|c|}
\hline $\begin{array}{l}\text { Rank in } \\
\text { the } \\
\text { District }\end{array}$ & Regions & $\begin{array}{l}\text { Technolog } \\
\text { ical } \\
\text { efficiency }\end{array}$ & $\begin{array}{c}\text { Ecological } \\
\text { energy } \\
\text { efficiency }\end{array}$ & $\begin{array}{c}\text { Efficien } \\
\text { cy } \\
\text { dynamic } \\
\text { s }\end{array}$ \\
\hline 1 & $\begin{array}{c}\text { Moscow } \\
\text { oblast }\end{array}$ & 3 & 1 & 4 \\
\hline 2 & $\begin{array}{c}\text { Moscow } \\
\text { oblast +the } \\
\text { city of } \\
\text { Moscow }\end{array}$ & 2 & 12 & 2 \\
\hline 3 & $\begin{array}{l}\text { Vladimir } \\
\text { oblast }\end{array}$ & 5 & 2 & 5 \\
\hline 4 & $\begin{array}{l}\text { the city of } \\
\text { Moscow }\end{array}$ & 1 & 16 & 1 \\
\hline 5 & $\frac{\text { Tambov }}{\text { oblast }}$ & $6-7$ & 14 & 3 \\
\hline 6 & Kursk oblast & $6-7$ & 5 & 9 \\
\hline 7 & $\begin{array}{l}\text { Lipetsk } \\
\text { oblast }\end{array}$ & 17 & 8 & 6 \\
\hline 8 & $\frac{\text { Yaroslavl }}{\text { oblast }}$ & 10 & 9 & 8 \\
\hline 9 & $\begin{array}{l}\text { Kaluga } \\
\text { oblast }\end{array}$ & 4 & 10 & 12 \\
\hline 10 & $\begin{array}{c}\text { Belgorod } \\
\text { oblast }\end{array}$ & 8 & 7 & 13 \\
\hline 11 & $\begin{array}{c}\text { Smolensk } \\
\text { oblast }\end{array}$ & 13 & 3 & 16 \\
\hline 12 & $\begin{array}{c}\text { Voronezh } \\
\text { oblast }\end{array}$ & 14 & 4 & 18 \\
\hline 13 & Tver oblast & 15 & 13 & 7 \\
\hline 14 & $\begin{array}{c}\text { Bryansk } \\
\text { oblast }\end{array}$ & 9 & 17 & 11 \\
\hline 15 & Ryazan oblast & 12 & 6 & 17 \\
\hline 16 & Orel_oblast & 11 & 18 & 14 \\
\hline 17 & $\begin{array}{c}\text { Ivanovo } \\
\text { oblast }\end{array}$ & 16 & 15 & 15 \\
\hline 18 & Tula oblast & 18 & 11 & 19 \\
\hline 19 & $\begin{array}{c}\text { Kostroma } \\
\text { oblast }\end{array}$ & 19 & 19 & 10 \\
\hline
\end{tabular}

The price, which the capital region has to pay for a high place in the ranking of technical potential, can be seen in table 3. By indicators of the human potential, the city of Moscow occupies the last line in the list, not much ahead of the capital the Moscow region is. The leading regions are the Chernozem regions of Orel, Tambov and Kursk, which also occupy high places in the human potential ranking. Attention is drawn to the low ranking of non-Chernozem regions, which objectively reflects the existing problems.

The ranking of the $\mathrm{CFO}$ regions by human potential is presented in table 3 .

Table 3. Ranking of the Central Federal District according to the criteria of human development in 2016

\begin{tabular}{|c|c|c|c|c|}
\hline $\begin{array}{l}\text { Ran } \\
\mathrm{k} \text { in } \\
\text { the } \\
\text { Dist } \\
\text { rict }\end{array}$ & Regions & $\begin{array}{c}\text { Population } \\
\text { viability }\end{array}$ & $\begin{array}{c}\text { Environ } \\
\text { mental } \\
\text { living } \\
\text { condition } \\
\text { s }\end{array}$ & $\begin{array}{c}\text { Dynam } \\
\text { ics of } \\
\text { viabilit } \\
\text { y and } \\
\text { living } \\
\text { conditi } \\
\text { ons }\end{array}$ \\
\hline 1 & Orel_oblast & 1 & 2 & 7 \\
\hline 2 & $\underline{\text { Tambov oblast }}$ & 3 & 3 & 4 \\
\hline 3 & Kursk oblast & 13 & 1 & 6 \\
\hline 4 & Ryazan oblast & 7 & 5 & 5 \\
\hline 5 & Bryansk oblast & 10 & 4 & 9 \\
\hline 6 & Belgorod oblast & 6 & 8 & 10 \\
\hline 7 & Kaluga_oblast & 5 & 6 & 14 \\
\hline 8 & $\begin{array}{c}\text { Voronezh } \\
\text { oblast }\end{array}$ & 14 & 9 & 3 \\
\hline 9 & Tula oblast & 4 & 10 & 18 \\
\hline 10 & Vladimir_oblast & 9 & 7 & 19 \\
\hline 11 & Moscow oblast & 2 & 17 & 15 \\
\hline 12 & $\begin{array}{c}\text { Smolensk } \\
\text { oblast }\end{array}$ & 8 & 13 & 13 \\
\hline 13 & Lipetsk oblast & 12 & 19 & 8 \\
\hline 14 & Tver oblast & 16 & 11 & 12 \\
\hline 15 & Kostroma oblast & 18 & 18 & 1 \\
\hline 16 & Ivanovo oblast & 17 & 14 & 2 \\
\hline 17 & $\begin{array}{c}\text { Moscow oblast } \\
\text { +the city of } \\
\text { Moscow }\end{array}$ & 11 & 16 & 16 \\
\hline 18 & $\underline{\text { Yaroslavl oblast }}$ & 19 & 12 & 11 \\
\hline 19 & $\begin{array}{l}\text { the city of } \\
\text { Moscow }\end{array}$ & 15 & 15 & 17 \\
\hline
\end{tabular}

The regions' natural potential ratings are shown in table 4 . Here naturally at the end of the list are the regions where large industrial enterprises are situated - namely, the Voronezh and Lipetsk regions and the city of Moscow, and the forest Kostroma region top-rates the list. But the presence of large 
machine-building enterprises, as it turns out, does not everywhere lead to a significant reduction in natural potential. This is noticeable in the rating place of the Vladimir region, which is the second largest in terms of natural potential.

Table 4. Ranking of the Central Federal District according to the criteria of the state and changes in natural potential in 2016

\begin{tabular}{|c|c|c|c|c|}
\hline $\begin{array}{l}\text { Rank } \\
\text { in the } \\
\text { Distri } \\
\text { ct }\end{array}$ & Regions & $\begin{array}{c}\text { Sustaina } \\
\text { bility and } \\
\text { integrity } \\
\text { of } \\
\text { ecosyste } \\
\text { ms }\end{array}$ & $\begin{array}{l}\text { Changes } \\
\text { in nature } \\
\text { sustainab } \\
\quad \text { ility }\end{array}$ & $\begin{array}{l}\text { Rank } \\
\text { in the } \\
\text { Distri } \\
\text { ct }\end{array}$ \\
\hline 1 & Kostroma oblast & 1 & 2 & 1 \\
\hline 2 & Vladimir_oblast & 6 & 1 & 2 \\
\hline 3 & $\underline{\text { Yaroslavl oblast }}$ & 3 & 7 & 3 \\
\hline 4 & Ivanovo oblast & 4 & 3 & 4 \\
\hline 5 & Tver oblast & 2 & 11 & 5 \\
\hline 6 & Moscow oblast & 7 & 4 & 6 \\
\hline 7 & $\begin{array}{c}\text { Moscow oblast } \\
\text { +the city of } \\
\text { Moscow }\end{array}$ & 9 & 5 & 7 \\
\hline 8 & Ryazan oblast & 11 & 6 & 8 \\
\hline 9 & Kaluga_oblast & 10 & 8 & 9 \\
\hline 10 & Smolensk oblast & 5 & 9 & 10 \\
\hline 11 & Bryansk oblast & 8 & 10 & 11 \\
\hline 12 & Tula oblast & 10 & 10 & 12 \\
\hline 13 & Orel_oblast & 14 & 13 & 13 \\
\hline 14 & Belgorod oblast & 19 & 14 & 14 \\
\hline 15 & Kursk oblast & 18 & 15 & 15 \\
\hline 16 & Tambov oblast & 13 & 16 & 16 \\
\hline 17 & $\begin{array}{l}\text { the city of } \\
\text { Moscow }\end{array}$ & 15 & 17 & 17 \\
\hline 18 & Lipetsk oblast & 16 & 19 & 18 \\
\hline 19 & Voronezh oblast & 17 & 18 & 19 \\
\hline
\end{tabular}

The places of the Central Federal District subjects rated by their integrated potential of sustainable development are shown in table 5 .
Table 5. Rating of the Central Federal District regions by the sustainable development potential

\begin{tabular}{|c|c|c|c|c|}
\hline $\begin{array}{c}\text { Rank } \\
\text { in the } \\
\text { Distri } \\
\text { ct }\end{array}$ & Regions & $\begin{array}{l}\text { Populat } \\
\text { ion } \\
\text { viabilit } \\
y\end{array}$ & $\begin{array}{c}\text { Environ } \\
\text { mental } \\
\text { living } \\
\text { condition } \\
\mathrm{s}\end{array}$ & $\begin{array}{l}\text { Dynamic } \\
\text { s of } \\
\text { viability } \\
\text { and } \\
\text { living } \\
\text { condition } \\
\text { s }\end{array}$ \\
\hline 1 & $\begin{array}{c}\text { Moscow } \\
\text { oblast }\end{array}$ & 1 & 11 & $5-6$ \\
\hline 2 & $\begin{array}{l}\text { Vladimir } \\
\text { oblast }\end{array}$ & 2 & 10 & 2 \\
\hline 3 & $\begin{array}{l}\text { Kaluga } \\
\text { oblast }\end{array}$ & 8 & 7 & 7 \\
\hline 4 & $\begin{array}{c}\text { Ryazan } \\
\text { oblast }\end{array}$ & 14 & 4 & 8 \\
\hline 5 & $\frac{\text { Yaroslavl }}{\text { oblast }}$ & 7 & $17-18$ & 3 \\
\hline 6 & $\begin{array}{c}\text { Smolensk } \\
\text { oblast }\end{array}$ & 10 & 12 & 9 \\
\hline 7 & Tver oblast & 12 & 14 & $5-6$ \\
\hline 8 & $\begin{array}{c}\text { Kostroma } \\
\text { oblast }\end{array}$ & 18 & 15 & 1 \\
\hline 9 & $\begin{array}{c}\text { Bryansk } \\
\text { oblast }\end{array}$ & 13 & 5 & 10 \\
\hline 10 & $\begin{array}{c}\text { Ivanovo } \\
\text { oblast }\end{array}$ & 16 & 16 & 4 \\
\hline 11 & $\frac{\text { Tambov }}{\text { oblast }}$ & 4 & 2 & $14-15$ \\
\hline 12 & Kursk oblast & 5 & 3 & $14-15$ \\
\hline 13 & Orel_oblast & 15 & 1 & 12 \\
\hline 14 & $\begin{array}{c}\text { Belgorod } \\
\text { oblast }\end{array}$ & 9 & 6 & 13 \\
\hline 15 & $\begin{array}{l}\text { the city of } \\
\text { Moscow }\end{array}$ & 3 & $17-18$ & 16 \\
\hline 16 & Tula oblast & 17 & 9 & 11 \\
\hline 17 & $\begin{array}{c}\text { Voronezh } \\
\text { oblast }\end{array}$ & 11 & 8 & $17-18$ \\
\hline 18 & $\begin{array}{l}\text { Lipetsk } \\
\text { oblast }\end{array}$ & 6 & 13 & $17-18$ \\
\hline
\end{tabular}

Topping the list is the Moscow region because of its technical potential. But other highly developed industrial regions, like the agricultural areas of the black earth region, because of the low indicators of natural potential (which reflects the strong disruption and degradation of the natural environment) and human potential (which reflects the low viability of the population), close the list, skipping forward the regions with average indicators having a more diversified economy and environmental management. 


\section{CONCLUSION}

Thus, it can be concluded that each region has its most promising economic sectors from the position of "green growth". In order to comply with environmental and economic interests in the sectors of economic activity, it is necessary to adapt foreign experience of ecologization of economic sectors or to borrow already accumulated experience from other subjects of the Russian Federation. The development of sectors of economic activity focused on "green economy" will allow the Russian regions to reduce the branch imbalances resulting in economic inequality of subjects of the country.

In order to increase the integral index of the regional economy ecologization in the constituent entities of the Russian Federation, it is necessary to stimulate the development of ecologically clean sectors of the economy. The choice of sectors of economic activity to activate the process of greening in them is due to the need to form ecology-oriented or "green economy" at the regional level.

In order to ensure sustainable environmental development of the regional economy, the following state policy measures should be applied:

- implementation of pricing based on the principles of sustainable development (e.g., refusal of inefficient subsidies, introduction of taxes on environmental pollution, etc.);

- state financing of investments into "environmental" infrastructure;

- target state support of innovations and developments in the field of ecological safety;

- encouraging the adoption of "green products" and the use of appropriate "green production" methods.

\section{Acknowledgment}

Article is prepared within researches on the project of the Russian fund of basic researches, the project No. 18-01001119.

\section{References}

[1] Kozhevnikova T.M., "Green economy" as one of the directions of sustainable development, Socio-economic phenomena and processes, 2013. - №3(49). - pp.78-82.

[2] Jashalova N.N., Theoretical aspects of the relationship between ecology and economy in the context of sustainable development, The strategy of economic development, 2012. - №44(185). - pp.26-34.

[3] Auzan A.A., About possibility of transition to the economic strategy based on specifics of the human capital in Russia, Journal of the NEA. 2015. - № 2 - pp. 243-248.

[4] Bautin V.M., "Green" economy as a new paradigm of sustainable development, Izvestia of Timiryazev agricultural Academy, 2015. №2. - pp.3-8.

[5] Vertakova, Y., Plotnikov, V. Problems of sustainable development worldwide and public policies for green economy, Economic AnnalsXXI 2017.- Volume 166, Issue 7-8, pp. 4-10

[6] Vertakova, Y., Larionov, V., Kondratova, E. Accounting of environmental imperatives in the public regulation of sustainable energetics development, Proceedings of the 29th International Business Information Management Association Conference - Education Excellence and Innovation Management through Vision 2020: From Regional Development Sustainability to Global Economic Growth, 2017, pp. 1982-1994

[7] Babkin, A.V., Plotnikov, V.A., Muraveva, S.V. Integrated industrial structures in the economy of Russia: Organizational forms and typology, Proceedings of the 25th International Business Information Management Association Conference - Innovation Vision 2020: From Regional Development Sustainability to Global Economic Growth, IBIMA 2015, 2015, pp. 1286-1293

[8] Babkin, A.V., Kudryavtseva, T.J. Identification and analysis of instrument industry cluster on the territory of the Russian Federation, Modern Applied Science, 2015, Volume 9, Issue 1, 2015, pp.109-118 